\title{
DEVELOPMENT OF AN AUTONOMOUS SPINAL INJURIES UNIT
}

\author{
M. SARRIAS Domingo, M.D. \\ instituto Guttman, Barcelona, Spain
}

IT is felt that it would interest Sir Ludwig Guttmann to have an overall account of the development of the unit in Barcelona named after him.

This paper is a continuation of a previous paper on the 'Organisation of an Autonomous Spinal Injuries Unit' (Sarrias-Domingo, 1967). The present data refer up to 30 April 1969 and compare with those of the previous paper which covered the period up to 30 June I967. The first patient was admitted on I December 1965 .

Present Staff and Facilities. I. The staff has increased from 34 to 58, and the Centre now employs an additional medical officer, a part-time radiologist and a part-time technician.

2. In September 1967 the structural alterations on the second floor of the hospital were completed and the capacity of the Centre has increased from 44 to 79 beds, distributed as follows:

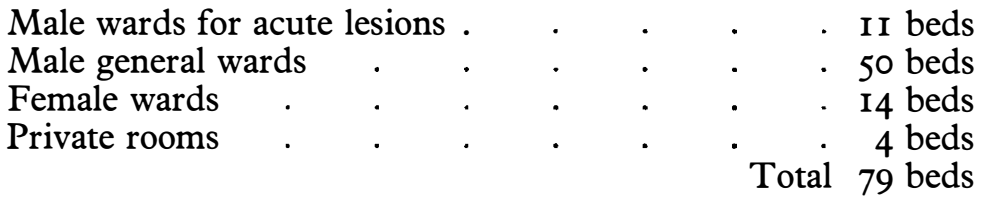

At present all beds are occupied.

3. New operating theatres with up-to-date equipment have been rebuilt in one wing of the second floor of the hospital. building.

4. A new X-ray department has also been installed in the second floor of the

5. Eight Egerton Stoke Mandeville turning-beds are available.

6. Regarding physical therapy, the surface area of the gymnasium is insufficient for the present requirements, and funds are being raised to build a new floor on to one of the wings of the hospital for a new gymnasium, and to build a therapeutic pool in the space made available on the ground floor when the gymnasium is moved to its new quarters.

7. The laboratory can now cover all routine requirements, including bacteriological examinations.

8. An outdoor basket-ball court has been built in the grounds of the Centre.

9. Workshops: The National Association of Civilian Invalids, the organisation on which the Instituto Guttmann is legally dependent, has been running a sheltered workshop during the past year for its associate members on the ground floor of the Centre. Space was a problem, therefore an old chapel attached to the main building of the hospital was divided up horizontally and the ground floor used for the sheltered workshop. The floor above it is now being equipped to house the occupational therapy department for the paraplegic unit.

Admissions and Turnover. From the opening of the Centre in December I965 to 30 April I969, I90 patients have been admitted to the Institute. 
Table I shows the patients admitted, the cause of their paraplegia or tetraplegia and the number of acute lesions (admissions within two weeks following injury).

\section{TABLE I}

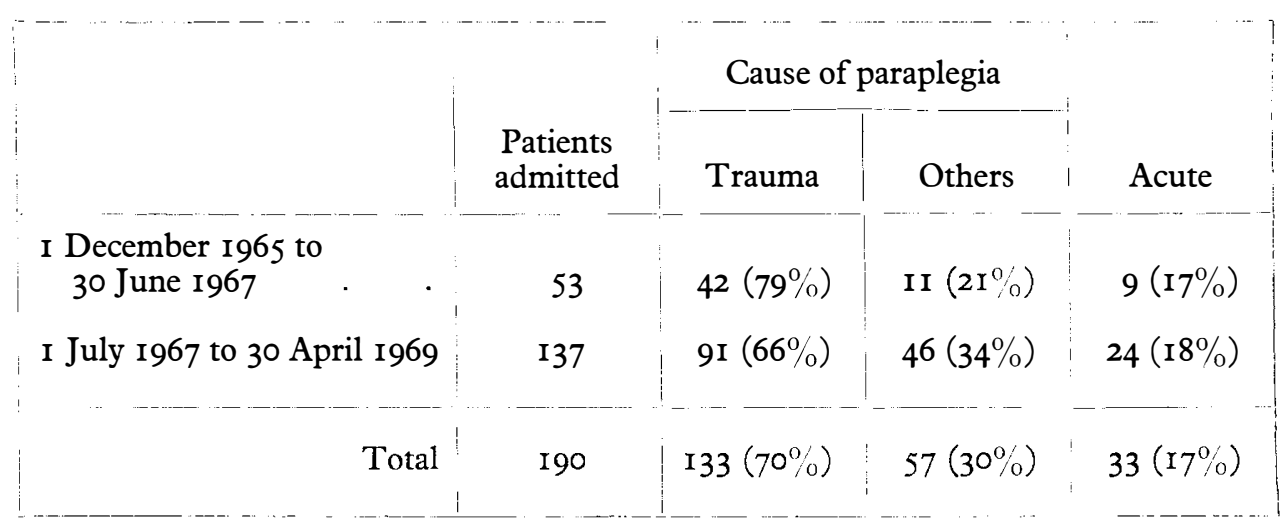

The distribution of patients, according to the level of their lesion is shown in Table II.

TABLE II

\begin{tabular}{|r|c|c|} 
& $\begin{array}{c}\text { I December I965 to } \\
\text { 30 June I967 }\end{array}$ & $\begin{array}{c}\text { I July I967 to } \\
\text { 30 April I969 }\end{array}$ \\
\hline Cervical & $8(15 \%)$ & $42(31 \%)$ \\
Thoracic I-6 & II $(21 \%)$ & $24(18 \%)$ \\
Thoracic 7-I2 & I5 $(28 \%)$ & $50(36 \%)$ \\
Lumbo-sacral & I9 $(36 \%)$ & $21(15 \%)$ \\
\hline Total & $53(100 \%)$ & I37 (100\%) \\
\hline
\end{tabular}

On 30 June 1967,23 patients had been discharged and one had been readmitted. From that time until 30 April 1969 a further 9I patients have been discharged (including 5 who died), twelve have been readmitted for treatment of complications and Io others have been readmitted for two to three days for their periodic check-up. Four of the patients in hospital at present are considered to be institutional. The average stay in the Centre for the 23 patients discharged up to 30 June 1967 was 224 days. For the 9I discharged since then the average stay has been 219 days.

General Management. The same lines mentioned in the previous paper are followed in the treatment of the fractured spine, care of the bladder, nursing, physiotherapy and routine complementary examinations. These are, on the whole, in accordance with the methods practised at the National Spinal Injuries Centre, Stoke Mandeville Hospital. 
Sources of Income and Running Costs. The percentage of paying patients has increased from 60 to 90 . This increase has been mostly due to the agreement between the Instituto Guttmann and the Spanish Social Security, which became effective from September 1967. Therefore the financial contributions from the National Association of Civilian Invalids and the Foundation for Physical Rehabilitation, who shared equally the running costs of the Centre once the contributions from paying patients had been deducted, are now less and it is likely that in 1969 they will be very small indeed.

The increased capacity of the Centre from 44 to 79 beds with its consequent increase of staff, together with new departments, facilities and raised costs of living, has increased the actual costs and overheads from $£ 4000$ per month to $£ 9000$. Thus the cost per bed daily amounts to approximately $£ 4$. IOs., on the basis of a 90 per cent. use of the total number of beds available.

Future of the Instituto Guttmann. Further developments in the projects of the Barcelona City Planning Council seem to confirm that the demolition of the present building will not take place for, at least, another seven to eight years. The Governing Body of the Institute is now considering the former plan of re-building the hospital on the present site rather than the other suggestion of building a new functional centre somewhere else in the suburban area of Barcelona.

Comments. The constant growth of this autonomous unit during a period of three years has created problems of space and, more important, of trained staff to provide the necessary specialised care of its patients. It is interesting to note that the number of beds for paraplegics in Spain under the Social Security was about 20 some eight years ago and is now over 200 . The total number of beds for paraplegics in the country is at present about 300, which include those from the Instituto Guttmann and some others in the mining areas of Northern Spain. New rehabilitation centres are being built and in most of them new paraplegic sections will be created.

When relating these facts to the distribution of patients according to the level of their lesions, Table II shows that in the first period the percentage of cervical injuries was 15 and in the second period it was $3 \mathrm{I}$, whereas the lumbo-sacral group was 36 per cent. in the first period and is per cent. in the second. On the other hand although an increase would have been expected in the percentage of patients with acute lesions admitted to the Centre, Table I shows no significant difference in the two periods under consideration. This can be accounted for by the fact that most paraplegic units under the Social Security deal with acute lesions (one of them in the same city of Barcelona), and that about 50 per cent. of the patients in the Instituto Guttmann have been referred from Social Security Centres.

\section{SUMMARY}

The development of the Instituto Guttmann over a period of less than two years is reported.

Problems of its growth, together with some aspects of the number and type of patients admitted are compared during two periods of its development.

\section{REFERENCES}

Sarrias-Domingo, M. (1967). Int. F. Paraplagia, 5, I70. 